\title{
PENGARUH FAMILY CONTROL TERHADAP PROFITABILITAS PADA PERUSAHAAN SEKTOR PERBANKAN YANG TERDAFTAR DI BURSA EFEK INDONESIA PERIODE 2012-2016
}

\author{
Dedi Andra Yanto, Aminar Sutra Dewi \\ Sekolah Tinggi Ilmu Ekonomi KBP \\ dediandrayanto@gmail.com
}

\begin{abstract}
ABSTRACK
Family Control this has a high sense of ownership and the company conducts oversight raises the opportunity to earn high profits and long-term orientation so family members choose to invest in the short term. This study aims to examine influences, family control on profitability in the banking sector which is listed on Indonesia Stock Exchange. Samples were taken from 6 companies in the financial sector which is listed on Indonesia Stock Exchange in the period 2012-2016, profitability measured by ROA (Riturn On Asset) and Family Control in view of what percent (\%) shares owned by the family. The analysis used in this study is a simple linear by using program eviews. From the test results are done shows that family control (FC) statistically has no effect significantly against Return On Asset (ROA).
\end{abstract}

Keyword : family Control and Return On Asset

\section{PENDAHULUAN}

Persaingan perusahaan merupakan aspek yang tidak dapat terlepas dari perusahaan dewasa ini. Perusahaan terus berusaha untuk memaksimalkan keuangannya demi mensejahterakan pemegang saham. Pemegang saham merupakan tujuan utama perusahaan untuk terusmelakukan pembenahan terkait dengan keuangan khususnya profitabilitasperusahaan. Jika membahas dunia bisnis memang tidak akan pernah ada habisnya. Selalu saja muncul bisnis baru dan pembisnis baru, entah itu tua atau muda. Indonesia sebagai negara berkembang tentunya menjadi salah satu lahan untuk mengembangkan bisnis dari berbagai bidang industri keuangan teruma sekali dalam perbankan. Perbankan akan membantu meningkatkan pertumbuhan ekonomi. Ini membuat para pengusaha segera membuka mata dan beraksi untuk membangun kerajaan bisnis mereka di tanah air Indonesia.

Dengan kerja keras dan mental baja membuat para pengusaha tanah air berhasil menancapkan bendera perusahaannya di tanah merah putih ini. Dari persaingan inilah perusahaan bisa mengkoreksi kesalahan atau kekurangan dari perusahaan lainnya. Perusahaan akan terus berusaha untuk memaksimalkan keuangannya demi mensejahterahkan perusahaan dan 
pemegang saham. Pemegang saham merupakan tujuan utama dari perusahaan untuk terus melakukan aktifitas perusahaan untuk meningkatkan profitabilitas perusahaan.

Profitabilitas adalah kemampuan perusahaan untuk mencapai keuntungan dan memperolehlaba yang semaksimal mungkin untuk kelangsungan dan kesejahteraan perusahaan.laba perusahaan dilihat dari penjualan, aktiva, ekuitas pemegang saham untuk menilai kinerja sebagai suatu persentase dari beberapa tingkat aktivitas atau investasi. Perusahaan dengan profitabilitas tinggi juga mampu menghasilkan laba yang tinggi sehingga mampu menjaga ekuitas tetap positif atau bahkan meningkat seiring dengan peningkatan laba ditahan.

Family control atau kepemilikankeluarga adalah perusahaan dengan pemegang saham pengendali terbesarnya (setidaknya memegang 10\% hak suara) merupakan keluarga, individu, atau perusahaan yang tidak terdaftar sebagai perusahaan publik, yang memberikan mereka hak untuk mengontrol manajemen. Mayoritas perusahaan yang terdaftar di Bursa Efek Indonesia merupakan perusahaan yang sebagian besar kepemilikannya dimiliki oleh keluarga. Kontrol keluarga sangat berperan penting terhadap perusahaan, perusahaan keluarga ini memiliki rasa kepemilikan yang tinggi dan peduli terhadap reputasi perusahaan,di karenakan perusahaan bertujuan untuk mewariskan bisnisnya kepada generasi-generasi selanjutnya.Sehingga mendorong anggota keluarga untuk melakukan pengawasan yang lebih erat, perusahaan yang melakukan pengawasan menyebabkan peluang untuk memperoleh laba yang tinggi dan berorentasi jangka panjang, sehingga anggota keluarga memilih berinvestasi jangka pendek.

Perusahaan keluarga juga berpengaruh negatif terhadap profitabilitas perusahaan,karena perusahaan keluarga ini sering mempertahankan pimpinan yang sudah tidak kompeten lagi, sehingga menghambat perekrutan-perekrutan manajemen yang lebih kompeten dan profesianal.Hal ini akan menggurangi tercapainya laba yang tinggi akan terjadi penurunan laba maka menujukkan profitabilitas yang rendah.Dari survei tersebut, 17\% dari nilai aset perusahaan-perusahaan dikendalikan oleh satu keluarga. Dengan tersebarnya mayoritas kepemilikan saham kepada investor luar, maka pelaksanaan hak kontrol para pemegang saham tersebut kepada pihak manajemen perusahaan menjadi lemah. Kelemahan tersebut memicu konflik kepentingan antara pihak manajemen dengan para pemegang saham. Pada sisi lain, semua pemegang saham yang tidak dalam posisi pengendali tidak memiliki potensi untuk melakukan respon satu pemegang saham terhadap pemegang saham lainnya. Dengan kata lain, kecil kemungkinan timbulnya konflik kepentingan antara para pemegang saham.

Profitabilitas merupakan indikator yang paling tempat untuk menggukur kinerja suatu bank, kinerja keuangan merupakan salah satu cara yang dapat dilakukan oleh pihak manajemen agar dapat memenuhi kewajiban terhadap para pemegang saham dan juga untuk mencapai tujuan yang telah di tetapkan oleh perusahaan. Profitabilitas perusahaan di lihat dari laporan keuangan, khususnya neraca perusahaan yang berisi informasi keuangan masa yang lalu, sementara dipihak lain beranggapan bahwa tercermin dari Profitabilitas perusahaan, family 
controladalah Suatu perusahaan yang dikelola oleh keluarga dengan kepemilikan lebih dari $10 \%$ dari modal luar Ciri-ciri perusahaan keluarga adalah sebagai berikut:Dimiliki oleh kelompok keluarga tunggal yang dominan dengan jumlah kepemilikan saham lebih dari $10 \%$, Dikelola oleh orang-rang yang berasal dari keluarga pemilik mayoritas saham (Westhead, 1997).

Pengaruh keluarga di dalam suatu perusahaan membuat peningkatan terhadap profitabilitas perusahaan maupun nilai perusahaan. Dimana ketika keluarga mempunyai kontrol di dalam perusahaan maka ia akan memilih anggota keluarganya sendiri dan anggota keluarga memiliki pengetahuan yang baik tentang bisnisnya, hal ini dikarenakan keluarga sudah turun temurun menjalankan perusahaan tersebut, sehingga hal tersebut akan berpengaruh pada pengambilan keputusan yang baik yang dapat meningkatkan profitabilitas bagi perusahaan. Selain itu pengaruh negatifnya adalah kontrol keluarga dalam perusahaan dapat menyebabkan ekspropriasi terhadap pihak minoritas sehingga muncul biaya yang tidak penting dan mengganggu profitabilitas perusahaan (Anderson\&Reeb, 2003 ; Claessens, et al., 2000).

Pengaruh dari kontrol keluarga di dalam suatu perusahaan juga dapat meningkatkan nilai dari perusahaan itu sendiri. Hal ini dapat dilihat dari salah satu kelebihan keluarga, yaitu perusahaan memiliki orientasi jangka panjang karena perusahaan keluarga ingin mewariskan perusahaan ke generasi berikutnya sehingga perusahaan akan memperhatikan keberlangsungan perusahaan dan akan sangat peduli terhadap reputasi perusahaan. Dengan adanya reputasi perusahaan yang baik maka perusahaan akan direspon positif oleh investor sehingga terjadi kenaikan harga saham dan meningkatkan nilai perusahaan. (McVey\&Draho, 2005; Wang, 2006). Berdasarkan teori yang di kemukakan dalam sebuah perusahaan perbankan bahwa family control mempunyai tujuan penting untuk dalam suatu perusahan perbank, maka hipotesis yang di ajukan adalah family control berpengaruh negatif dan tidak signifikan terhadap profitabilitas pada perusahaan.

\begin{tabular}{|c|c|c|}
\hline $\begin{array}{c}\text { Family Control } \\
(\mathrm{X})\end{array}$ & $\begin{array}{c}\text { Profitabilitas } \\
\text { (Y) }\end{array}$ \\
\cline { 2 - 3 } & \\
\hline
\end{tabular}

\section{METODE PENELITIAN}

Jenis penelitian yang ada dalam penelitian ini adalah penelitian kuantitatif dan kualitatif yaitu menggunakan data yang berbentuk angka atau kualitatif yang di angkakan scoring (sugyono 2012). Penelitian kuanlitatif adalah pendekatan ilmiah terhadap pengambilan keputusan manajerial dan ekonomi. Penelitian ini dilakukan menggunakan penelitian kuantitatif, karena penelitian ini bersifat menganalisis laporan keuangan pada bank go public yang terdaftar di bursa efek indonesia dan menafsirkan hasilnya dalam bentuk angka-angka.

Populasi dalam penelitian ini adalah perusahaan sektor keuangan yang terdaftar di Bursa Efek Indonesia. Dari data di bursa efek indonesia telah ada 23 perusahan keluarga perbankan yang terdaftar di bursa efek indonesia .dari jumlah populasi dalam penelitian sebanyak 23 bank, populasi yang ada akan di ambil sejumlah tertentu sebagai sampel.

Dalam pengambilan sampel ini di lakukan dengan metode purposive sampling, yaitu metode pengambilan sampel berdasarkan kriteria-kriteria 
dan pertimbangan tertentu (sugiyono, 2012). Berdasarkan kriteria penentuan sampel:

1. Sampel merupakan perusahaan sektor perbankan yang tercatat di Bursa Efek Indonesia sampai akhir 2016.

2. Sampel yang dipilih memiliki laporan tahunan yang lengkap pada tahun 2012-2016.

3. Sampel yang dipilih, perusahaan yang memiliki ROA positif $(+)$

Berdasarkan kriteria di atas terdapat 23 perusahaan sektor keuangan yang terdaftar di BEI dan beroperasi di indonesia pada tahun 2012-2016, bank yang memenuhi persyaratan sebagai sampel penelitian berjumlah 6 bank yang memenuhi syarat.pengamatan yang akan di olah dalam penelitian ini adalah hasil perkalian antara jumlah bank dengan jumlah pengamatan yaitu selama (lima) 5 periode (tahun 2012 sampai dengan 2016). Jadi total pengamatan dalam penelitian ini untuk kelompok bank keluarga go publik menjadi 30 data observasi. Sehingga, jumlah sampel dalam penelitian ini telah memenuhi ketentuan jumlah data pengamatan minimal $(n=30)$. Definisi Operasional

Tabel.1

Defenisi Operasional Variabel

\begin{tabular}{|c|c|c|c|c|}
\hline Variabel & Notasi & Pengertian & Rumus & Sumber \\
\hline $\begin{array}{l}\text { Return } \\
\text { On Asset }\end{array}$ & ROA & $\begin{array}{l}\text { kemampuan suatu perusahaan } \\
\text { (aktiva perusahaan) dengan } \\
\text { seluruh modal yang bekerja d } \\
\text { dalamnya untuk menghasilkan } \\
\text { laba operasi perusahaan } \\
\text { EBIT)atau perbandingan laba } \\
\text { usaha dengan modal sendiri dan } \\
\text { modal asing yang digunakan untul } \\
\text { menghasilkan laba dan dinyatakan } \\
\text { dalam persentase }\end{array}$ & $\begin{array}{c}\text { Roa }= \\
\frac{\text { Lababersih }}{\text { Totalaset }} \times 100\end{array}$ & $\begin{array}{l}\text { Sus an } \\
\text { Irawati ,20 } \\
06\end{array}$ \\
\hline $\begin{array}{l}\text { Family } \\
\text { control }\end{array}$ & $\mathrm{Fc}$ & $\begin{array}{l}\text { Perusahaan } \begin{array}{l}\text { yang } \\
\text { keluarga di }\end{array} \text { miliki } \\
\text { lebih dari } \\
\text { lo\% }\end{array}$ & Kepemilikan & $\begin{array}{l}\text { Siregar, } \\
2008\end{array}$ \\
\hline
\end{tabular}

Untuk memperoleh data yang relavan sehingga dapat di jadikan landasan dalam proses analisis, maka dalam penelitian ini penulis menggunakan teknik penggumpulan data dengan metode observasi dan metode pendokumentasian.Metode observasi merupakan telah pustaka dengan mengamati skripsi-skripsi dan jurnal-jurnal terdahulu yang di gunakan dalam penelitian ini, Sedangkan metode dokumentasi merupakan salah satu data yang di lakukan dengan cara mengambil data sekunder berupa laporan tahunan dari perusahaan yang bersangkutan. Data dalam penelitian ini di peroleh dari media internet dengan cara mendownload melalui situs bank yang menjadi objek penelitian. 
Teknik analisis ini di gunakan Untuk menguji dan membuktikan hipotesis yang diajukan maka penelitian ini menggunakan Eviews 6. Eviews adalah program yang banyak digunakan dalam pendidikan, pemerintah dan industri. Eviews, yang merupakan singkatan Views Ekonometrik, adalah versi baru dari paket statistik untuk memanipulasi data time series. Meskipun sebagian besar Eviews dirumuskan oleh ekonomi, program itu sendiri juga dapat digunakan dalam bidang-bidang studi, seperti sosiologi, statistik, keuangan, dll.

Statistik deskriptif adalah penyajian data secara numerik. Statistik deskriptif menyajikan ukuran-ukuran numerik yang sangat penting bagi data sampel. Statistik deskriptif juga digunakan untuk mengetahui nilai ratarata, minimal, maksimal dan standar deviasi dari variabel-variabel yang diteliti.

Uji asumsi klasik digunakan untuk mendapatkan penduga koefsien regresi yang mempunyai error terkecil atau model regresi yang dihasilkan adalah mempunyai sifat BLUE (Best Linier Unbiased Estimate) atau mempunyai sifat yang Linear, tidak biasa dan varian minimum. Adapun uji asumsi klasik adalah sebagai berikut:

Uji normalitas adalah uji untuk melihat apakah distribusi data mengikuti pola distribusi normal atau tidak, atau menguji apakah dalam sebuah model regresi, variable dependen, variable independen, atau keduanya mempunyai distribusi normal atau tidak. Model regresi yang baik adalah distribusi data normal dan merata.uji normalitas bertujuan untuk menguji apakah model regresi, variabel pengganggu atau residual mempunyai distribusi normal atau tidak. Data terdistribusi normal dapat dilihat dari jika nilai Probability Jargue-Bera> tingkat alpha 5\%, maka data terdistribusi secara normal, sebaliknya jika nilai Probability Jargue-Bera< tingkat alpha 5\%, maka data tidak terdistribusi secara normal.

Uji autokorelasi digunakan untuk melihat ada tidaknya autokorelasi, autokorelasi adalah korelasi yang terjadi diantara anggota-anggota dari serangkaian pengamatan yang tersusun dalam data time series. Apabila terjadi autokorelasi didalam suatu model, artinya varian sampel tidak menggambarkan varian populasinya.Dalam keadaan seperti ini model regresi yang dihasilkan tidak dapat digunakan untuk menaksir nilai variabel dependen pada variabel independen tertentu.Model penelitian yang baik adalah tidak terjadi autokorelasi. Uji yang digunakan untuk mendeteksi adanya gejala autokorelasi adalah Durbin-Watson Statistic Test. Jika Durbin-Watsonnya antara -2 sampai 2 berarti tidak terjadi autokorelasi. (Gujarati, 2003).

Analisis regresi linear sederhana adalah analisis statistik yang berfungsi untuk mengguji sejauh mana hubungan sebab akibat antara variabel independen $(\mathrm{X})$ terhadap variabel dependen $(\mathrm{Y})$. Faktor penyebab pada umumnya di lambangkan dengan $X$ atau di sebut juga dengan predictor sedangkan variabel akibat di lambangkan dengan $\mathrm{Y}$ atau di sebut juga Response. Regresi linear sederhana atau sering di singkat dengan SLR (Simple Linear Regression) juga salah satu metode statistik yang di 
pergunakan dalam produksi untuk melakukan peramalan ataupun prediksi tentang karakteristik kualitas maupun kuantitas.

Penelitian ini menggunakaan eviews untuk memperoleh semua nilai yang diinginkan model analisa regresi dan pengujian secara statistik. Pada penelitian ini, teknik analisis data di lakukan dengan menggunakan teknik analisa regresi linear sederhana dan model untuk menggolah data dan membahas data yang telah di peroleh dan untuk menguji hipotesis yang di ajukan.

Keterangan:

$$
\text { profitability }=\alpha+\beta f c
$$

$\alpha$ : koofesien konstanta

$\beta$ : koofesien regresi

Roa:return on assset

FC :Family Control

\section{HASIL DAN PEMBAHASAN}

\section{Deskriptif Statistik Variabel Penelitian}

Tabel 2

Deskriptif Statistik variabel penelitian

\begin{tabular}{cccccc}
\hline Variabel & $\mathbf{N}$ & Minimum & Maksimum & Mean & $\begin{array}{c}\text { Standar } \\
\text { Deviasi }\end{array}$ \\
\hline FC & 30 & 0.125500 & 0.882500 & 0.519553 & 0.254258 \\
ROA & 30 & 0.032000 & 3.088000 & 1.040600 & 0.939132
\end{tabular}

Sumber: Data diolah.

Data rasio ROA terendah (minimum) adalah 0,032 yang terdapat pada perusahaan CIMB pada tahun 2016 dan yang tertinggi (maksimum) adalah 3.088000 yang terdapat pada perusahaan BCA pada tahun 2016 dengan rata-rata ROA yaitu sebesar 1.040600. Sementara standar deviasi sebesar 0.939132 yang menunjukkan simpangan data yang relatif besar karena nilainya lebih besar dari pada mean yaitu sebesar 1.040600 .

Data family control terendah (minimum) adalah 0.125500 dan tertinggi (maksimum) adalah 0.882500 dengan rata-rata family control yaitu 0.519553 serta standar deviasi sebesar 0.254258 yang menunjukkan simpangan data yang relatif kecil karena nilai lain lebih kecil dari pada nilai maen yaitu 0.519553

\section{Uji Normalitas Data}

Tabel 3

Hasil Uji Normalitas Data

\begin{tabular}{cccc}
\hline Variabel & $\mathbf{N}$ & Jorque-Bera & Probabilitas \\
\hline ROA & 30 & 0.624817 & 0.731682
\end{tabular}

Sumber: Data diolah 
Dari tabel diatas dapat dilihat bahwa nilai variabel memiliki nilai diatas standar yaitu > 0,05 dapat disimpulkan bahwa variabel terdistribusi secara normal.

\section{Uji otokolerasi}

Tabel 4

Hasil Uji Durbin-Watson

\begin{tabular}{cc}
\hline Model & Durbin-Watson \\
\hline $\mathbf{1}$ & 0.279141
\end{tabular}

\section{Sumber: Data diolah}

Dari hasil uji Durbin-Watson pada tabel diatas terlihat bahwa tidak terjadi otokolerasi karena nilai Dw antara $-2<0.279141<2$.

\section{Analisis Regresi Linear Sederhana}

\section{Tabel 5}

\section{Hasil Uji Regresi Linear Sederhana Dan Model}

Dependent Variable:ROA

Method: Least Squares

Date: 02/21/18 Time:23:21

Sample: 20012030

Included observations: 30

\begin{tabular}{lrlrr}
\hline \hline \multicolumn{1}{c}{ Variable } & Coefficient & Std. Error & t-Statistic & Prob. \\
\hline \hline \multicolumn{1}{c}{ FC } & -1.785200 & 0.613657 & -2.909118 & 0.0070 \\
C & 1.967054 & 0.353273 & 5.568079 & 0.0000 \\
\hline \hline R-squared & 0.232098 & Mean dependent var & 1.040600 \\
Adjusted R-squared & 0.204673 & S.D. dependent var & 0.939132 \\
S.E. of regression & 0.837529 & Akaike info criterion & 2.547618 \\
Sum squared resid & 19.64073 & Schwarz criterion & 2.641032 \\
Log likelihood & -36.21428 & Hannan-Quinn criter. & 2.577502 \\
F-statistic & 8.462970 & Durbin-Watson stat & 0.368827 \\
Prob(F-statistic) & 0.007025 & & \\
\hline
\end{tabular}

Dari tabel 4.5 di atas, dapat di tuliskan persamaan sebagai berikut :

\section{Uji Hipotes is}

$$
\mathrm{ROA}=1.967054-1.785200 \mathrm{FC}
$$

\section{Uji Koenfisien Secara parsial ( t)}

\section{Tabel 6}

Uji T

\begin{tabular}{cccc}
\hline Variabel & t-hitung & t-tabel & Probabilitas \\
\hline FC & -2.909118 & 0,05 & 0.0070
\end{tabular}

Data: Data Diolah

Pada tabel 4.6 dapat di simpulkan bahwa nilai pada tabel t-hitung pada variabel FC yaitu sebesar -2.909118, dengan tinkat probabilitas yaitu 
sebesar $0.0070<0,05$, dapat di simpulkan bahwa Ha di terima dan H0 di tolak

\section{Pembahasan Pengaruh FC terhadap ROA}

hasil pengujian regresi yang telah dilakukan, di peroleh bahwa variabel Family Control (FC) mempunyai pengaruh negatif dan tidak signifikan -1.785200 terhadap Return On Asset (ROA) dengan nilai probabilitas $0,0070<0,05$.

Family Control signifikan terhadap probabilitas pada sektor keuangan yang menjadi sampel penelitian. Walau secara mayoritas sebesar $67.4 \%$ perusahaan sektor keuangan adalah perusahaan family contror dan menunjukkan bahwa ROA pada perusaan family control lebih tinggi di bandingkan pada perusahaan non keluarga, tetapi kepemilikan ini tidak berpengaruh signifikan terhadap probabilitas perusahaan.

Teori mengatakan bahwa family control memang tdak sinigfikan, karna di lihat dari koenfisien regresinya 0,0070, sedangkan standar profitabilitas 0,05 , maka family kontrol memiliki arah yang negatif terhadap probabilitas.

Hasil ini sesuai dengan hasil penelitian dahulu yang di lakukan oleh Lidian Harianto dan Juniarti (2014) dengan judul pengaruh family control, firm risk, firm size dan firm age terhadap profitabilitas dan nilai perusahaan pada perusahaan sektor keuangan. Bahwa family control tdak berpengaruh signifikan terhadap profitabilitas pada sektor keuangan, dan Carollen Thesman dan Juniarti (2014) dengan judul penelitian pengaruh family control terhadap profitabilitas dan nilai perusahaan pada sektor pertanian.

\section{SIMPULAN}

Berdasarkan hasil penelitian pada perusahaan di sektor perbankan yang terdaftar di BEI periode 2012-2016, di kemukakan kesimpulan bahwa, variabel Family Control (FC) mempunyai pengaruh negatif dan tidak signifikan -1.785200 terhadap Return On Asset (ROA) dengan nilai probabilitas $0,0070<0,05$.

\section{TERIMAKASIH}

Penulis menyadari bahwa dalam penulisan skripsi ini penulis tidak terlepas dari berbagai hambatan dan rintangan, namun berkat bantuan dari berbagai pihak maka segala macam hambatan dapat teratasi. Untuk itu penulis ingin menyampaikan ucapan terima kasih dan penghargaan yang tulus kepada:

1. Febryandhie Ananda SE,M.Siselakuketua STIE “KBP” Padang.

2. Ibu Febsri SusantiSEI, MM selaku ketua program studi Manajemen.

3. Ibu Aminar Sutra Dewi sebagai pembimbing yang dengan penuh perhatian memberi bimbingan pemikiran dan dorongan semangat serta masukan dan arahan dalam pembuatan skripsiini.

4. Ibu Maria Magdalena,Spd,MMselakupenasehatakademik program studi Manajemen. 


\section{DAFTAR PUSTAKA}

Afriyeni, A., \& Marlius, D. (2017). Analisis Pengaruh Harga Saham Perdana Terhadap Abnormal Return Yang Diterima Investor Studi Pada Bursa Efek Indonesia. https://doi.org/10.31219/osf.io/8z7hx

Afriyeni, A., \& Marlius, D. (2018). Analisis Pengaruh Informasi Prospektus Perusahaan Terhadap Initial Return Saham Pada Pasar Perdana Di Bursa Efek Indonesia. https://doi.org/10.31219/osf.io/kt6c4

Afriyeni, A., \& Marlius, D. (2019). Analisis Faktor-Faktor Yang Berpengaruh Terhadap Ketepatan Waktu Penyampaian Laporan Keuangan Pada Perusahaan Yang Listing Di Bursa Efek Indonesia. https://doi.org/10.31219/osf.io/rv4qf

Afriyeni, A., \& Marlius, D. (2019). Analisis Tingkat Pengembalian Dan Risiko Investasi (Studi Pada Industri Manufaktur Yang Terdaftar Di Bursa Efek Indonesia). https://doi.org/10.31219/osf.io/cfb92

Agustin, E., \& Dewi, A. S. (2019). Pengaruh Good Corporate Governance Dan Leverage Terhadap Kinerja Keuangan Perbankan Yang Terdaftar Di Bursa Efek Indonesia. https://doi.org/10.31219/osf.io/h9xgp

Aminar sutra dewi. (2016). 'Pengaruh Rasio Camel Terhadap Return Saham Pada PT Bank Mandiri Tbk. (Jurnal pendidikan ekonomi dan Bisnis), Vol 8, No 2, pp. 120-129.

Arifin, Zaenal. (2003). "Masalah Agensi dan Mekanisme Kontrol pada Perusahaan dengan Struktur Kepemilikan Terkonsentrasi yang Dikontrol Keluarga: Bukti Empiris dari Perusahaan Publik di Indonesia." Tesis Tidak Dipublikasikan, Program Studi Ilmu Manajemen Program Pascasarjana Fakultas Ekonomi Universitas Indonesia.

Brigham, Eugene F dan Joel F. Houston.(2001). Manajemen Keuangan. Jakarta:Erlangga.

Claessens, Stijn, Simeon Djankov, Joseph P. H. Fan, and Larry H. P. Lang,(2002).Disentangling the incentive and entrenchment effects of large shareholdings, Journal of Finance, Vol. 57, pp. 2741-2771.

D., \& Dewi, A. S. (2018). Pengaruh Penerapan Good Corporate Governance Terhadap Kinerja Keuangan Perbankan Yang Terdaftar Di Bursa Efek Indonesia. https://doi.org/10.31219/osf.io/w5agv

Fama, Eugene.F., and Michael C.Jensen. (1983). Agency Problems and Residual Claims, Journal of Law and Economics, Vol. 26, No. 2, Corporation and 
Private Property: A Conference by the Hoover Institution, University of Chicago Press, pp. 327-349. http//www.jstor.org/stable/725105.

García Meca, E.; Sanchez Ballesta (2011): "Does ownership structure monitor analyst forecast accuracy?"Journal ofInternational Accounting Auditing andTaxation, 20, 73-82.

Gibson, J.L, Ivan Cevich and Donelly. (1995). Organisasi dan Manajemen: Perilaku,Struktur, dan Proses. Terjemahan. Jakarta: Erlangga.

Ibrahim, H., Samad, F.A. (2011). Corporate governance mechanisms and performance of public-listed family-ownership in Malaysia.International Journal ofEconomics and Finance. Vol. 3, No. 1, pp. 105-115.

Iskandar, E. D. (2011, October 31). Credit Suisse Kuliti 3.568 Bisnis Keluarga di Asia.SWA.Retrieved September 9, 2013, from http//swa.co.id/listedarticles/23548.

Ismail, N., \& Mahfodz, A. N. (2009).Sucession planning in family firms and its implications on business performance.Journal of AsiaEntrepreneurship and Sustainability, 10(3), 86-107

Indrawati,T. dan Suhendro. 2006. Determinasi Capital Structure Pada Perusahaan Manufaktur di Bursa Efek Jakarta Periode 2002-2004, Jurnal Akuntansi dan Keuangan Indonesia, Vol. 3, No. 1, Januari-Juni, hlm. 77-105.

Melania, V., \& Dewi, A. S. (2019). Pengaruh Good Corporate Governance Terhadap Kinerja Keuangan Dengan Manajemen Laba Sebagai Variabel Intervening Pada Perusahaan Perbankan Yang Terdaftar Di Bursa Efek Indonesia. https://doi.org/10.31219/osf.io/jrpcd

Putri, A. D., \& Mayliza, R. (2019). Pengaruh Good Corporate Governance Dan Leverage Terhadap Kinerja Keuangan Pada Perbankan Yang Terdaftar Di BEI. https://doi.org/10.31219/osf.io/b8he7

Rode, C. D., \& Dewi, A. S. (2019). Pengaruh Good Corporate Governance Dan Leverage Terhadap Kinerja Keuangan Perbankan Yang Terdaftar Di Bursa Efek Indonesia. https://doi.org/10.31219/osf.io/rn6cs 